\title{
Konsep Makkiyah dan Madaniyyah Dalam Al-Qur'an (Sebuah Analisis Historis-Filosofis)
}

\author{
M. Bekti Khudari Lantong \\ Bekti.lantong@iain-manado.ac.id
}

\begin{abstract}
This article would try to elaborate an important concept in the Qur'an which deal with the process of revelation. Major of ulama devided the process of revelation into two periods, namely Makkah period (before hijrah) and Madinah period (after hijrah). According to Abdullahi Ahmed An-Na'im and his teacher, Mahmoud Mohamed Taha, this two periods of revelation contains different doctrines and teachings. Makkah period (Makkiyah) expressed a universal-democratic-egalitarianism doctrines of Islam. Whereas, Madinah period (Madaniyyah), is considered to be sectarian and discriminative. In this period, the prophet and his adherents created a city-state with a multi-religious and multi-cultural community. Therefore, they need a concrete and strict rules and regulations to manage the new state and new community. An-Na'im stated that most of the verses in the Qur'an which deal with law and regulations revealed through this period, including the relation between muslim and nonmuslim community.
\end{abstract}

Key words: concept, Makkah period, Madinah period, al-Qur'an

Abstrak. Artikel ini akan mencoba untuk menguraikan konsep penting dalam Al Qur'an yang berhubungan dengan proses penyataan. Mayoritas ulama membagi proses penyataan menjadi dua periode, yaitu periode Makkah (sebelum hijrah) dan periode Madinah (setelah hijrah). Menurut Abdullahi Ahmed An-Na'im dan gurunya, Mahmoud Mohamed Taha, dua periode wahyu ini mengandung doktrin dan ajaran yang berbeda. Periode Mekah (Makkiyah) menyatakan doktrin universal-demokratis-egalitarianisme Islam. Padahal, periode Madinah (Madaniyyah), dianggap sektarian dan diskriminatif. Pada periode ini, nabi dan pengikutnya menciptakan negara-kota dengan komunitas multi-agama dan multibudaya. Oleh karena itu, mereka membutuhkan aturan dan peraturan yang konkrit dan ketat untuk mengelola negara baru dan komunitas baru. An-Na'im menyatakan bahwa ayat-ayat dalam Al Qur'an yang berhubungan dengan hukum dan terungkap selama periode ini, termasuk hubungan antara Muslim dan komunitas non-Muslim.

Kata kunci: konsep, periode Mekkah, periode Madinah, Alquran

\section{A. Pendahuluan}

Al-Qur'an bagi kaum muslimin adalah "verbum dei" (Kalam Allah) yang diwahyukan kepada nabi Muhammad Saw. melalui perantaraan Jibril selama kurang lebih dua puluh tiga tahun. Kitab suci ini memiliki kekuatan luar biasa yang berada diluar kemampuan apapun :

"Seandainya kami turunkan al-Qur'an ini kepada sebuah gunung, maka kamu akan melihatnya tunduk terpecah-pecah karena gentar kepada Allah" (QS. alHasyr[59]:21). Kandungan pesan Ilahi 
yang disampaikan Nabi Saw. pada permulaan abad ke-7 M. itu telah meletakkan basis untuk kehidupan individual dan sosial kaum muslimin dalam segala aspeknya. Bahkan masyarakat muslim mengawali eksistensinya dan memperoleh kekuatan hidup dengan merespon dakwah alQur'an. Itulah sebabnya al-Qur'an berada tepat di jantung kepercayaan muslim dan berbagai pengalaman keagamaanya. Tanpa pemahaman yang semestinya terhadap alQur'an, kehidupan pemikiran dan kebudayaan kaum muslimin tentunya akan sulit dipahami. ${ }^{1}$ Dalam hal ini, kiranya kita perlu memahami lebih jauh aspek kesejarahan al-Qur'an, karena bagaimanapun al-Qur'an diturunkan dalam perspektif realitas masyarakat Arab waktu itu. Meminjam istilah Prof. Amin Abdullah bahwa teks al-Qur'an tidak bisa dilepaskan dari konteks masyarakat ruang dan waktu - di mana al-Qur'an itu turun. Inilah yang akan dibahas secara ringkas dalam tulisan ini.

\section{B. Konsep Makkiyah dan Madaniyyah}

Secara kronologis periode turunya alQur'an dibagi menjadi dua, yaitu; periode Makkah (makkiyah) dan periode Madinah (Madaniyyah). Pembagian seperti ini didasarkan atas dua parameter yaitu, tempat (al-makan) dan waktu (al-zaman). Menurut Abdullahi Ahmed An-Na'im, pesan yang terkandung dalam ayat-ayat Makkiyah merupakan pesan Islam yang abadi dan fundamental, yang menekankan martabat yang inheren pada seluruh umat manusia, tanpa membedakan jenis kelamin (gender), keyakinan agama, dan ras. Pesan-pesan ini ditandai dengan persamaan antara laki-laki dan perempuan dan kebebasan penuh untuk

${ }^{1}$ Taufik Adnan Amal, Rekonstruksi Sejarah alQur'an, (Yogyakarta: FkBA, 2000), h.1 memilih dalam beragama dan keimanan, prinsipnya adalah 'ishmah', kebebasan untuk memilih tanpa ancaman atau bayangan kekerasan dan paksaan apapun. Sedangkan pesan Madinah adalah kompromi praktis dan realistis, ketika tingkat tertinggi dari pesan Makkah tidak dapat diterima oleh masyarakat-sejarah abad VII M. Oleh karena itu, kalau ayatayat yang turun dalam periode Makkah dapat disebut sebagai (menurut istilah AnNa'im) ayat-ayat "universal-egalitariandemokratis", maka ayat-ayat Madinah dapatlah dinamai ayat-ayat "sektariandiskriminatif".2

Hijrah menandai tidak saja perubahan dramatik dalam pertumbuhan jumlah umat Islam dan pembentukan masyarakat politik atau negara Islam pertama di Madinah; melainkan juga peralihan yang signifikan dalam materi pokok dan isi misi Nabi. Secara umum disepakati bahwa selama periode Makkah al-Qur'an lebih banyak berisi tentang ajaran agama dan moral, tidak menyatakan norma-norma politik dan hukum secara khusus, yang baru dikembangkan pada periode Madinah. Penjelasan tentang perubahan ini adalah karena pada periode Madinah ini al-Qur'an harus memberikan respon terhadap kebutuhan sosial-politik yang konkrit dalam suatu komunitas yang dibangun. Dengan kemerdekaan untuk mengembangkan institusi-institusi yang mereka miliki dan menerapkan normanorma agama baru mereka, umat Islam memerlukan ajaran dan tuntunan norma yang lebih terinci. ${ }^{3}$

Mahmoud Mohamed Taha, seorang pemikir Islam kontemporer dari Sudan, mengatakan bahwa ada perbedaan yang

2 Abdullahi Ahmed An-Na'im, Dekonstruksi Syari'ah, (Yogyakarta : LKiS, 1994), h.Viii-ix

${ }^{3}$ Ibid, h.27-28 
signifikan antara pesan Makkah dan pesan Madinah. Nabi diperintahkan oleh alQur'an untuk menyebarkan Islam di Makkah dengan cara damai dan tertutup, sesuai dengan kebebasan penuh untuk memilih, misalnya dalam QS. anNahl[16]:125, dan QS. al-Kahfi[18]:29. Substansi dari pesan Makkah menekankan pada nilai-nilai keadilan dan persamaan yang fundamental dan martabat yang melekat pada seluruh manusia. Sebagai contoh, al-Qur'an selama periode Makkah selau menyapa seluruh manusia, menggunakan kata-kata seperti; "Wahai manusia" dan "wahai anak Adam". Sedangkan pesan Madinah mulai membedakan antara laki-laki dan perempuan, umat Islam dan non-muslim, dalam status hukum dan hak mereka di depan hukum. Semua ayat yang menjadi dasar diskriminasi terhadap perempuan dan non-muslim merupakan ayat-ayat Madinah. Sebagai contoh, al-Qur'an surat ke empat yang dikenal sebagai surat anNisa (surat tentang perempuan), berisi aturan-aturan yang lebih rinci tentang perkawinan, perceraian, waris dan semacamnya dengan pengaruh diskriminasinya terhadap perempuan, diwahyukan selama masa Madinah. ${ }^{4}$ Tumpang tindih antara periode Makkah dan Madinah, lebih mengantarkan pada satu pemahaman tentang perubahan gradual ketimbang perubahan yang cepat dalam isi pesan tersebut. Sebagai hasil dari peralihan isi pesan dan metode seruanya, beberapa orang berpura-pura masuk Islam tanpa keyakinan murni yang mendalam. Fenomena ini sebagian besar secara jelas ditunjukan oleh acuan al-Qur'an yang berulang-ulang pada kalimat al-munafiqun (kaum munafik) dalam wahyu Madinah,

4 Mahmoud Mohamed Taha, The Second Message of Islam, (Syracuse : Syracuse University Press, 1987), h.23 sedangkan dalam wahyu Makkah tidak ada ayat semacam itu. Dengan berkurangnya tingkat atau bentuk kekerasan selama periode Makkah, orang memiliki kebebasan penuh untuk memeluk Islam atau menolaknya. Dengan hilangnya tingkat kebebasan secara gradual selama periode Madinah, banyak orang kafir menunjukkan iman pada tampak luarnya untuk menghindarkan akibat negatif (menyelamatkan diri) bila mereka menampakkan kekafiranya.

\section{Konsepsi Al-Qur'an Tentang Non- Muslim: Analisis Historis-Filosofis}

Islam dilahirkan dalam suatu lingkungan yang amat keras, dan menerima reaksi yang sangat bermusuhan, berbagai ancaman dan serangan dari sukusuku Arab abad ke-VII, karena itu umat Islam awal harus berperang untuk tetap bertahan. Nabi dan para sahabat akhirnya menguasai seluruh jazirah Arab beberapa saat menjelang wafatnya. Norma hubungan antar suku yang ada sangat tergantung pada penggunaan atau ancaman penggunaan kekuatan (force) untuk mempertahankan berbagai hak bahkan hak untuk ada. ${ }^{5}$

Penggunan ancaman kekerasan juga merupakan norma di kalangan berbagai entitas atau sistem politik kawasan itu, termasuk dua imperium raksasa sebelah Timur Laut dan Barat Laut Arabia, Sasaniah dan Bizantium (imperium Romawi). Sehingga, ketika negara Islam pertama dibangun di Arabia pada abad VII, kekerasan merupakan metode dasar untuk mengatur "hubungan-hubungan internasional". Oleh karena itu, tidak dapat dielakkan bahwa Islam mengesahkan penggunaan kekerasan dalam hubungan-

${ }^{5}$ Haykal, Life of Muhammad, h. 15-16 dan Fred M. Donner, The Early Islamic Conquest, (Princeton: Princeton University Press, 1981), h. 20ff 
hubungan muslim dengan non-muslim. Namun, dalam melakukan itu syari'ah memperkenalkan norma-norma baru untuk mengontrol berbagai alasan untuk melakukan peperangan, juga dalam praktik nyatanya. ${ }^{6}$

Mengingat perang di kalangan sukusuku Arabia dan entitas politik kawasan tersebut didorong oleh pertimbanganpertimbangan seperti kehormatan suku, perebutan wilayah dan ketamakan ekonomi, maka syari'ah (al-Qur'an) membatasi penggunaan kekerasan dalam hubungan internasional, hanya untuk mempertahankan diri dan penyebaran agama Islam. Bagi umat Islam, hanya itulah alasan yang sah untuk melakukan perang. Selebihnya, umat Islam dibatasi oleh ketentuan-ketentuan yang mengatur perang yang benar. Sebagai contoh, sebelum menggunakan kekerasan dalam menyebarkan Islam, mereka dituntut untuk menawarkan sisi lain dari manfaat memeluk kepercayaan itu tanpa harus berperang. Jika peperangan tidak dapat dielakkan, maka dibatasi hanya terhadap pasukan tentara yang bertugas berperang dan hanya dilakukan di medan perang.

Banyak ayat al-Qur'an yang diwahyukan setelah hijrah ke Madinah pada tahun 622 M menekankan kohesi internal komunitas muslim dan berusaha membedakannya dari komunitaskomunitas lain dalam term-term permusuhan dan antagonistik. Selama masa Madinah, al-Qur'an berulang-ulang memerintahkan umat Islam untuk saling menolong antara satu dengan yang lain dan untuk tidak tolong menolong dengan non-muslim, serta memerangi mereka yang berkawan dan bersekutu dengan non-muslim. Sehingga ayat-ayat al-Qur'an surat al-'Imran[3]:28, an-Nisa[4]:144, alEast, h. 353ff.
Anfal[8]:72-73, at-Taubah[9]:23 dan 71, dan surat al-Mumtahanah[60]:1 mewajibkan umat Islam menghindari kaum kafir sebagai 'awliya' (kawan, pembantu dan pendukung) serta memerintahkan pertemanan dan mendorong kerjasama diantara umat Islam sendiri. Demikian pula, surat alMaidah[5]:51 menginstruksikan kaum muslim untuk tidak mengambil kaum Yahudi dan Kristen sebagai pelindung (awliya), seperti mereka memperlakukan umat Islam yang lain, dan barang siapa orang Islam - yang bekerja sama dengan mereka (bersahabat), maka ia menjadi salah seorang dari golongan mereka.

Ayat-ayat tersebut dan sunnah yang terkait menyatakan konteks umum dimana sumber-sumber yang secara khusus berhubungan dengan penggunaan kekuatan terhadap non-muslim dipahami dan diterapkan oleh umat Islam awal. Ayat-ayat di atas yang berkenaan dengan larangan untuk bergaul dan bekerja sama dengan kaum Yahudi dan Kristen dalam segala hal, diwahyukan selama periode Madinah, bukan periode Makkah awal. Sumber-sumber itu harus dilihat sebagai dorongan psikologis untuk mempertahankan hidup dan kohesi umat Islam yang mudah diserang, dalam suatu lingkungan sosial dan fisik yang keras dan bermusuhan.

Istilah yang umum dipakai menyangkut penggunaan kekerasan dalam hubungan internasional adalah jihad. Arti harfiah kata jihad adalah pengerahan daya dan upaya, termasuk - tetapi tidak hanya perang. Sehingga, di satu pihak, baik alQur'an maupun sunnah menggunakan istilah jihad dalam pengertian lebih luas tentang pengerahan kekuatan, namun terkadang sama sekali tidak terkait dengan penggunaan kekerasan. Di dalam sejumlah ayat al-Qur'an seperti QS. alBaqarah[2]:18, QS. al-Maidah[5]:54, dan 
QS. al-Anfal:72, istilah jihad dan derivasinya digunakan untuk menyebut pengerahan kekuatan, baik dalam peperangan maupun dalam masa damai. Bahkan terhadap orang-orang kafir, QS. alFurqan[25]:52 memerintahkan nabi dan umat Islam untuk menggunakan al-Qur'an dalam jihad terhadap orang kafir. Ini jelas merujuk pada pengunaan kekuatan dan menurut argumen al-Qur'an, bukan kekuatan senjata. Dalam sunnah ada pernyataan nabi Saw. yang amat terkenal yang menggambarkan bahwa penggunaan kekuatan dalam perang digolongkan sebagai jihad kecil (jihad al-asghar), sedangkan pengerahan kekuatan dalam perdamaian dan upaya pribadi melaksanakan perintah Islam digolongkan sebagai jihad besar (jihad al-akbar) dan agung. Dalam sunnah yang lain, nabi menyatakan bahwa bentuk jihad yang paling baik adalah mengatakan kebenaran di depan penguasa yang zhalim dan menindas.

Ayat-ayat al-Qur'an yang secara jelas membenarkan penggunaan kekuatan oleh kaum muslimin terhadap non-muslim diwahyukan di Madinah, setelah nabi dan para sahabatnya berhijrah dari Makkah pada tahun 622M. Menurut perkiraan Ibn Katsir dalam tafsirnya yang terkenal, ayatayat al-Qur'an yang pertama memerintahkan kaum muslimin menggunakan kekuatan dalam jihad/qital terhadap orang kafir adalah QS. alBaqarah[2]:190-193 dan QS. alHajj[22]:39, yang mungkin diartikan masing-masing sebagai berikut :

"Dan perangilah di jalan Allah mereka yang memerangi kamu, tetapi janganlah kamu melanggar batas, karena sesungguhnya Allah tidak menyukai orangorang yang melampaui batas. Bunuhlah mereka dimana pun kamu jumpai, usirlah mereka dari tempat mereka mengusir kamu (dari Makkah); dan fitnah itu lebih besar bahayanya dari pada pembunuhan, dan janganlah kamu memerangi mereka di masjid al-Haram, kecuali jika mereka memerangi kamu disana. Maka jika mereka memerangi kamu disana, maka bunuhlah mereka. Demikianlah balasan bagi orangorang kafir. Tetapi jika mereka berhenti (dari memusuhimu), maka sesungguhnya Allah Maha Pengampun lagi Maha Penyayang. Perangilah mereka sehingga tidak ada penindasan lagi dan yang ada hanyalah keadilan dan keimanan kepada Allah; Tetapi jika mereka berhenti (dari memusuhimu), maka jangan ada lagi permusuhan, kecuali terhadap orang-orang yang melakukan kezhaliman".

"Telah diizinkan (berperang) bagi orang-orang yang diperangi, karena sesungguhnya mereka telah dianiaya. Dan sesungguhnya Allah benar-benar Maha Kuasa menolong mereka itu, (yaitu) orangorang yang telah diusir dari kampung halaman mereka tanpa alasan yang benar, kecuali karena mereka berkata: "Tuhan kami hanya Allah". Dan sekiranya Allah tiada menolak (keganasan) sebagian manusia dengan sebagian yang lain, tentulah telah dirobohkan biara-biara Nasrani, gereja-gereja, sinagog-sinagog kaum Yahudi dan masjid-masjid, yang di dalamnya banyak disebut nama Allah".

Seluruh surat at-Taubah yang diidentifikasi oleh Ibn Katsir diwahyukan pada tahun kesembilan hijrah, yakni sekitar tahun $631 \mathrm{M}$, secara umum diterima sebagai surat yang diturunkan menjelang penutupan pewahyuan alQur'an. Ayat-ayat dalam surat ini, seperti ayat $5,12,29,36,73$, dan 123 , berisi pembenaran paling jelas bagi penggunaan kekuatan untuk melawan non-muslim dan secara umum telah mrngganti (nasakh) ayat-ayat tertentu yang melarang atau membatasi penggunaan kekuatan. Khususnya ayat 5 surat ini dikatakan telah mengganti lebih dari seratus ayat al- 
Qur'an yang semula memerintahkan umat Islam untuk menggunakan cara damai dan argumentasi untuk meyakinkan orangorang kafir agar memeluk Islam. ${ }^{7}$

Beberapa kesimpulan dapat ditarik dari telaah terhadap al-Qur'an menyangkut penggunaan kekuatan oleh kaum muslim terhadap non-muslim. Kesimpulan pertama, adalah bahwa hal ini secara eksklusif sebagai fenomena Madinah (berhubungan dengan periode Madinah setelah nabi hijrah dari Makkah). Sebaliknya, sebagian besar ayat al-Qur'an yang mempersilakan kebebasan memilih dalam kepercayaan dan kesamaan konsekuensi dan tidak melakukan diskriminasi terhadap non-muslim dalam masalah hukum jika diimplementasikan di dalam syari'ah, adalah ayat-ayat periode Makkah. Sebelum hijrah ke Madinah tahun $622 \mathrm{M}$, tidak ada keabsahan hukum dalam al-Qur'an untuk menggunakan kekuatan terhadap non-muslim.

Kesimpulan kedua, ada suatu progres di dalam pembenaran al-Qur'an terhadap penggunaan kekuatan oleh kaum muslim untuk melawan non-muslim dari penggunaan kekuatan untuk mempertahankan diri sampai penggunaan kekuatan dalam penyebaran Islam. Tetapi karena al-Qur'an surat al-Taubah di antara wahyu terakhir, diambil oleh beberapa ahli hokum muslim untuk menghapus, atau dihapus untuk tujuan syari'ah, seluruh pewahyuan dengan jelas tidak sesuai dengan ayat-ayat al-Qur'an.

Kesimpulan ketiga, Penggunaan kekuatan tidak diijinkan kecuali untuk mempertahankan diri dan menyebarkan Islam. Sejumlah penulis modern mengklaim bahwa syari'ah mengijinkan penggunaan kekuatan hanya untuk

${ }^{7}$ Lihat Zayd, al-Naskh fil al-Qur'an al-Karim, 1:289-501-83; dan Ahmad Hasan, The Early Development of Islamic Jurisprudence, h. 67-68. mempertahankan diri. Klaim ini tidak ada dasar fakta baik di dalam al-Qur'an maupun sunnah. Sampai menjelang wafatnya nabi, pembenaran penggunaan kekuatan dalam menyebarkan Islam sama seperti mempertahankan diri. Tidak masuk akal untuk menyatakan bahwa umat Islam awal sedang dalam keadaan mempertahankan diri ketika mereka menaklukan dan memerintah seluruh wilayah Syria, Irak, Afrika bagian Utara dan Spanyol bagian Selatan di Barat dan Persia, serta India bagian Utara di Timur. Seperti dengan jelas ditunjukkan oleh praktek nabi terakhir dan para khalifahnya, demikian juga sejarah ekspansi Islam, syrai'ah membatasi dan mengatur penggunaan kekuatan oleh kaum muslim terhadap non-muslim, tidak hanya dalam mempertahankan diri, melainkan juga sebagai sarana penyebaran Islam.

Dengan demikian, banyak kita temukan riwayat dari nabi dan khalifah sesudahnya, yang memerintahkan tentara muslim untuk menawarkan kesempatan pihak non-muslim untuk memeluk Islam. Jika mereka menerima tawaran itu, tidak boleh menggunakan kekuatan untuk melawan mereka. Jika pihak non-muslim menolak ajakan muslim untuk memeluk Islam, dan kebetulan mereka Ahli Kitab, maka mereka ditawarkan pada pilihan kedua, dimasukkan pada posisi dzimmah dengan kaum muslim, dengan syarat mereka setuju membayar jizyah, dan tunduk kepada kedaulatan umat Islam dengan imbalan jaminan jiwa dan harta benda mereka, serta dibolehkan mempraktekan agama mereka serta menerapkan hukum mereka sendiri.

\section{Kesimpulan}

Periode Makkah dan Madinah ternyata bukan sekadar rentang tempat dan waktu (locus dan tempus) semata, 
tetapi ia - dengan konteks dan kultur masyarakat tempat turunya yang berbeda - berakibat pada pemaknaan dan penafsiran yang berbeda pula terhadap alQur'an. Sehingga, sejatinya penafsiran

\section{DAFTAR PUSTAKA}

Amal, Taufik Adnan, Rekonstruksi Sejarah

Al-Qur'an, (Yogyakarta: FkBA, 2000)

An-Na'im, Abdullah Ahmed, Dekonstruksi Syari'ah : Wacana Kebebasan Sipil, HAM dan Hubungan Internasional dalam Islam (Yogyakarta : LKiS, 1994) terhadap al-Qur'an bukanlah sesuatu yang sudah "final", melainkan bersifat dinamis, sesuai dinamika dan konteks kehidupan manusia itu sendiri. Wa Allah a'lam bi alshawab

Haykal, Muhammad Husayn, The Life of Muhammad, terj. Isma'il al-Faruqi, (Indianapolis: American Trust Publication, 1976)

Khadduri, Madjid, and Herbert Liebesny, Law in the Middle East, (Washington D.C.: Middle East Institute, 1955)

Taha, Mahmoud Mohamed, The Second Message of Islam, (Syracuse : Syracuse University Press, 1987) 